\title{
最適制御理論による自動飛行制御装置のシンセシス*
}

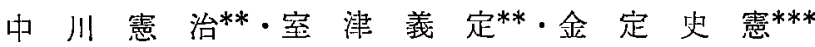

\section{Synthesis of Automatic Flight Control Systems \\ Using Optimal Control Theory}

Kenji Nakagawa, Yoshisada Murotsu and Fuminori Kanesada

\begin{abstract}
This paper proposes the method of synthesizing linear flight control systems by applying optimnl control theory associated with quadratic performance index. For this problem, the method of utilizing the root-square-locus technique has been developed by RYNASKI and others. In the present method, instead, the synthesis is done by evaluating quantitatively the performance of the transient responses with the aid of digital and analog computers. The design procedure is illustrated on an attitude-control system for the conventional aircraft and an automatic stabilization equipment for the VTOL aircraft. A comparison is made of the results obtained by classical root-locus method, the root-square-locus method and the present method. Thus, it is shown that the present method yields an excellent control system design.
\end{abstract}

\section{1. まえがき}

線形定係数の自動制御系の最適構成に関する古典理 論として代表的なものには，根軌跡法，ボード線図， ナイキスト線図等がある.とれらは，いずれす，先に 制御方式を仮定しておいて，望ましい応答が得られる ように，試行錯請的に調整可能なゲイン定数を沈める あのである.しかし（1）望ましい応答に対する判定 基準が明確に設定されていないので，判定があいまい である，(2) 仮定した方式が最適の構成であるという 保証がない，(3) 多くのフィード・バック回路を持つ 系や多変数制御系については計算が困難である，とい う欠点を持っている.

以上のような古典理論の欠点を補うために発展した のが最適制御理論であって, 制御系の動作性能を定量 的に判定する基準として評洒関数を設定し，この評価 関数を最大または最小にする最適制御系を求めるもの である、とのような最適制废理諭を用いると，(1) 評

* 昭和 42 年 4 月 5 日 日本航空学会年会および昭和 42 年11月16日 日本航空学会飛行機シンポジュームに て輩演，昭和 43 年 6 月 11 日原稿受理

** 大阪府立大学工学部航空工学教室

*** 大阪府立大学工学部数理工学教室
佂の基隼が明確である，(2) 制衔与式およびそのゲイ ン定教の值は評価関数から解析的に誘導されるので， 古典理諭のように最適構成交試行錯䛊的に模索する必 要がない，(3）多変数制御系に対しても，同一の手法 を適用して系統的に設計が可能である，などの利点を 持っている，しかし，乙れを実際の制御系の設計に適 用するためにはなお多くの問題が残されている. 主要 な問題点の $1 つ$ つ, 最適制御理諭では最初に評価関数 を与える必要があるが，一般に設計要求をむりてんだ 適切な評価関数の選択が困難であるという点にある. 実際, 従来の最適制御理諭の応用例では, 評価関数を 天下り的に与えているが，飛行制御装置等では，明確 な評価関数を与えられる場合はほとんどなく，過渡応 答によって制伟系の良否が判定される場合が多いので ある. 著者は前論文 ${ }^{1}$ で，線形定係数系に対して，評 価関数として, 状態変数と制御変数に関する 2 次形式 を選んだ場合について，との問題の一つの解決法を示 した.すなわち，評価関数に含まれる各変数に対する 重み係数の值と, 結果として得られる最適采の特性根 の值との関係を求为，我行性基準を考慮して，重み係 数の值を決定した．評佂関数しして 2 次形式を選んだ 理由は，(1) 制御法則が線形よなる，(2) 重み係数の 数值を与えるとゲイン定数の值がすぺて決まる，(3) このゲイン定数を求める計算はりッカチ方程式に帰着 し電子計算機で解ける，などの利点があるためであ る.

この論文では，2 次形式の評佂関数に基づいて前論 文と異なった手法で，さらに具体的な線形フィードバ ック制御系のシンセシスの方法を提案する。これは， 評洒関数の重み係数の值を変えると種々の過渡応答特 性を持つ最適系が求まることに酋目して，最適系の中 からさらに過渡応答の最良の系を見いだそうとするす のである，との方法の特徴は，(1) 最適制御理論をシ ンセシスの数学的手段として用いる，(2) 古典的根軦 跡法や著者の前諭文の手法では，特性根の値から過渡 特性を判定するのに対し，計算㙨を用いて過渡特性を 数值的に評価する，(3) 以上の計算はすべて電子計算 機によって処理する，ととである. 
応用例之して，普通の航空機の䋛の姿勢制御装置 と, 垂直離着陸航空機（VTOL 譏）の横の自動安定 装置のシンセシスの問題を取り扱い，この手法を説明 する.

\section{2. 過渡特性の数値評価による方法}

2.1 最適制御理論による定式 以下においては， 線形定係数系について最適制御理諭によって得られた 結果22を用いる. 要約するとつぎのようである.

線形定係数系の連铺力程式は，状態べクトルを用い てつぎのように書ける.

$$
\dot{\boldsymbol{x}}(\tau)=\boldsymbol{A} \boldsymbol{x}(\tau)+\boldsymbol{B u}(\tau)
$$

ここに, $\boldsymbol{x}: n \times 1$ 状態べクトル, $\boldsymbol{u}: m \times 1$ 制御ベク トル, $\boldsymbol{A}: n \times n$ 係数マトリックス, $\boldsymbol{B}: n$ $\times m$ 係数マトリックス,

である. 2 次形式の評価関数は，

$$
I=\int_{t}^{\infty}\left(\boldsymbol{x}^{\prime} \boldsymbol{Q} \boldsymbol{x}+\boldsymbol{u}^{\prime} \boldsymbol{R} \boldsymbol{u}\right) d \tau
$$

ここに Q: $n \times n$ 対称な非負重み係数マトリックス,

$\boldsymbol{R}: m \times m$ 対称で正定な重み係数マトリック z,

である. (2・1) 式の系で， $I$ を最小にする制御（最適 制御) $\boldsymbol{u}^{*}$ は,

$$
\boldsymbol{u}^{*}=-\boldsymbol{R}^{-1} \boldsymbol{B}^{\prime} \boldsymbol{K} \boldsymbol{x}
$$

で与えられる. ここに $\boldsymbol{K}$ は $n \times n$ 対称マトリックス であって，つぎの $P(t)$ に関するリッカチ方程式の定 常解である.

$$
-\dot{\boldsymbol{P}}=\boldsymbol{P A}+\boldsymbol{A}^{\prime} \boldsymbol{P}-\boldsymbol{P B R} \boldsymbol{R}^{-1} \boldsymbol{B}^{\prime} \boldsymbol{P}+\boldsymbol{Q}
$$

すなわち，

$$
\boldsymbol{K}=\lim _{t \rightarrow-\infty} \boldsymbol{P}(t)
$$

したがって，系の状態方程式と評価関数の重み係数マ トリックス $\boldsymbol{Q}, \boldsymbol{R}$ が与えられると，最適制御 $\boldsymbol{u}^{*}(2 \cdot 3)$ のゲイン係数は (2・4) 式を解いて得られる.

2.2 シンセシスの手順 以上述べたように状態变 数上制御変数の重み係数マトリックスの要素の值が与 えられると，最適制街法則 $\boldsymbol{u}^{*}$ のゲイン係数が決まり， との最適系の過渡応答が求められる. しかし，重み係 数の值を変更すればゲイン係数の值が異なり過渡応答 あまた変わってくる.すなわち，重み係数のそれぞれ の值に対して最適系が得られるが，それらの過渡応答 は異なったすのである. ことで，種々の重み係数に対 する最適系の中からさらに過渡応答が最す望ましいる のを採用する．とのときアナログ計算機によって過渡 応答の特性を数值的に評洒する方法をとる．その順序 はつぎのようである.

（1）状態変数の中から評価すべき変数を選び，評 価関数を定加る。
（2）ディジタル計算機またはアナログ計算機によ り，重み係数を系統的に変えてリッカチ方程式を解 き，各重み係数の值に対して，ゲイン定数の最適值を 求める.

（3）アナログ計算機により，各場合の過渡応答を 求めて, 設計の基準となる量，たとえば，最大操作量 の值や，出力の偏差の 2 乗積分値等の数値を計算し， 重み係数に対してプロットする。

（4）以上の数値加ら定量的に判定して, 適当な重 み係数の值老選ぶと, 最適のゲイン定数が決定される。

\section{3. 航空機の姿勢制御装置のシンセシス}

航寽機に自動的に一定の水平直線飛行をさせる縦の 姿勢制御装置のシンセシスを考える. 数值例として, BLAKELOCK の教科書3) に述べてある 4 発ジェット輸 送機の巡航時の姿勢制御装置をとることにする．この 場合の短周期近似の運動方程式はつぎのようになる。

$$
\begin{aligned}
& \frac{m U}{s_{q}} \dot{\alpha}-c_{z \alpha} \alpha-\frac{m U}{s_{q}} \dot{\theta}+\frac{m g \sin \theta_{0}}{s_{q}} \theta=c_{z \delta} \delta_{e} \\
& -\frac{c}{2 U} c_{m \dot{\alpha} \dot{\alpha}}-c_{m \alpha} \alpha+\frac{I_{y}}{s_{q c}} \ddot{\theta}-\frac{c}{2 U} c_{m q} \dot{\theta} \\
& \quad=c_{m \delta_{e}} \delta_{e}
\end{aligned}
$$

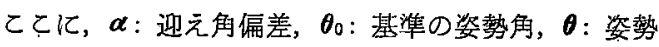
角偏差， $\boldsymbol{\delta}_{\epsilon}$ : 昇降舵操舵角，

である. 上式に， $\theta_{0}=0$ および機体の空力特性值を代 入すると，

$$
\left.\begin{array}{l}
13.78 \dot{\alpha}+4.46 \alpha-13.78 \dot{\theta}=-0.246 \delta \\
0.0558 \dot{\alpha}+0.619 \alpha+0.514 \dot{\theta}+0.192 \dot{\theta}
\end{array}\right\}
$$$$
=-0.710 \delta \text {. }
$$

こなる。昇降舵サーボは近似的に

$$
\dot{\delta}_{e}=-10 \delta_{e}-10 \delta_{c}
$$

で与えられる.ここに $\delta_{c}$ はサーボへのス力であって， 従来用いられてきたような，姿勢俑と姿勢角速度をフ ィードバックする方式では，

$$
\delta_{c}=-K_{\theta} \theta-K_{\dot{\theta}} \dot{\theta}
$$

と書ける.

従来は，制御方式をこのように仮定した上で古典理 論を適用し，ゲィン定数 $K_{\theta}, K_{\dot{\theta}}$ の最適值を求めた。 この制御系のブロック線図を第 1 図に示す.

以下では，2で述べたシンセシスの手法を適用する. (3.2) および (3.3) 式において状態変数を， $x_{1}=\theta$, $x_{2}=\dot{\theta}, x_{3}=\alpha, x_{4}=\delta_{e}$, 制御変数を $\delta_{c}$ による上状態方 程式はつぎのようになる。

$$
\left[\begin{array}{c}
\dot{x}_{1} \\
\dot{x}_{2} \\
\dot{x}_{3} \\
\dot{x}_{1}
\end{array}\right]=\left[\begin{array}{cccc}
0 & 1 & 0 & 0 \\
0 & -0.481 & -1.17 & -1.38 \\
0 & 1 & -0.324 & -0.018 \\
0 & 0 & 0 & -10
\end{array}\right]\left[\begin{array}{l}
x_{1} \\
x_{2} \\
x_{3} \\
x_{4}
\end{array}\right]
$$




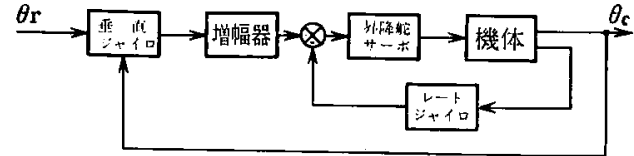

(a)

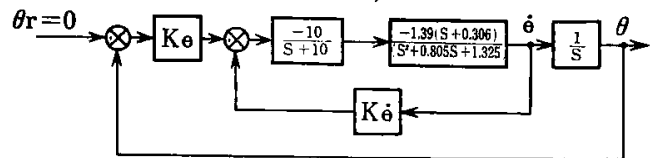

(b)

符 1 図 说来の姿沙制御装通 (BLAKELOCK)

$$
+\left(\begin{array}{c}
0 \\
0 \\
0 \\
-10
\end{array}\right)^{\delta_{c}}
$$

この例では，姿势角の制御を考えているので，評価 すべき出力変数としては，姿劣角 $\theta$ だけを選ぶととに する. この上き，評価関数は次式で表わされる.

$$
I=\int_{t}^{\infty}\left(\gamma_{11} x_{1}^{2}+\delta_{c}^{2}\right) d \tau
$$

最適制佂法則は, 従来用いられてきた (3.4) 式と異

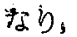

$$
\begin{aligned}
\delta_{c} & =-K \theta \theta-K_{\dot{\theta}} \dot{\theta}-K_{\alpha} \alpha-K_{\delta} \delta_{e} \\
& \triangleq 10\left(K_{41} x_{1}+K_{4}{ }^{2} x_{2}+K_{43} x_{3}+K_{44} x_{4}\right)
\end{aligned}
$$

で与えられる，ての系の蓝成は第2図のようになる。 ここに，ゲイン定数 $K_{41}, \cdots, K_{44}$ は, 対称マトリック ス $P$ に関するつぎのリッカ千方程式の定常解, $K_{i j}$ $=\lim _{t \rightarrow \infty} P_{i j}(t)$ で与えられる:

$$
\begin{aligned}
& \dot{P}_{11}=-10^{2} P_{14}^{2}+\gamma_{11} \\
& \dot{P}_{12}=P_{11}-0.481 P_{12}+P_{13}-10^{2} P_{14} P_{24} \\
& \dot{P}_{13}=-1.17 P_{12}-0.324 P_{13}-10^{2} P_{14} P_{34} \\
& \dot{P}_{14}=-1.38 P_{12}-0.018 P_{13}-10 P_{14} \\
& \quad-10^{2} P_{14} P_{44} \\
& \dot{P}_{22}=2 P_{12}-0.962 P_{22}+2 P_{23}-10^{2} P_{24}^{2} \\
& \dot{P}_{23}=-1.17 P_{22}+P_{13}-0.805 P_{23}+P_{33} \\
& \quad-10^{2} P_{24} P_{34} \\
& \dot{P}_{24}=-1.38 P_{22}+P_{14}-0.018 P_{23} \\
& \quad-10.481 P_{24}+P_{34}-10^{2} P_{24} P_{44} \\
& \dot{P}_{33}=-2.34 P_{23}-0.648 P_{33}-10^{2} P_{34}{ }^{2} \\
& \dot{P}_{34}=-1.38 P_{23}-1.17 P_{24}-0.018 P_{33} \\
& \quad-10.324 P_{34}-10^{2} P_{34} P_{44} \\
& \dot{P}_{44}=-2.76 P_{24}-0.036 P_{34}-20 P_{44}-10^{2} P_{44}{ }^{2}
\end{aligned}
$$

ディジタル計算機を用いて, $t=0$ におるる初期值 $P_{11}=-P_{44}=0$ から出発して上の連立方程式を解き, $t \rightarrow \infty$ 亿おける定常㺟を求好る. このさい, 重み係数 $\gamma_{11}$ を系統的に 変化させて計算を行ない，各場合に対 するゲイン定数 $K_{41}, \cdots, K_{44}$ を求めておく．つきにと

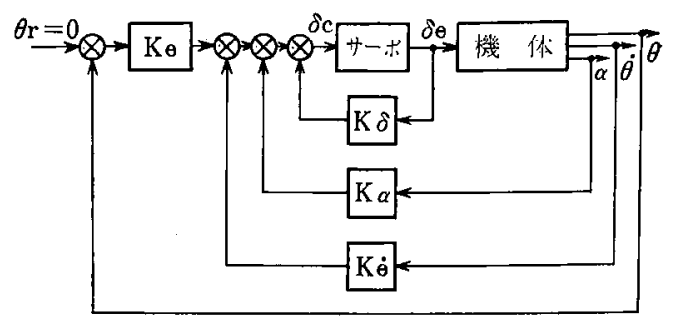

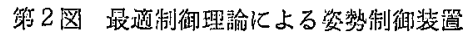

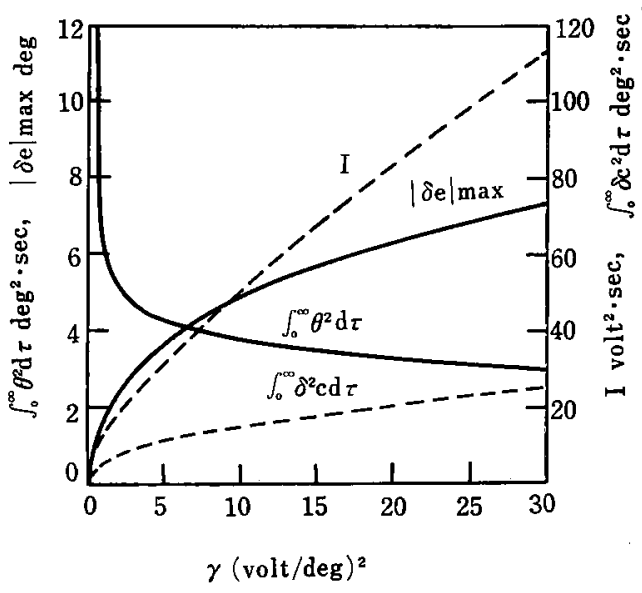

籍 3 図 重み系数之過渡応答特性の関係

のようにして求まったゲイン定数の值に対する過滨応 答をアナログ計算機によって求める.このさい,てれら の過渡応答を評価する特性值を計算する.この例では， 評価関数の值 $I$, 姿勢角偏差の 2 裴皘分值 $\int_{0}^{\infty} \theta^{2} d \tau$, 制御信穾の2 乘㧼分值 $\int_{0}^{\infty} d_{c}{ }^{2} d \tau$ おょよび操作星の最大值 $\left|\delta_{e}\right|_{\max }$ を計算した。.これらの数值を重み係数 $\gamma_{11} に$ 対してプロットしたあのが第 3 図である. 自則飛行制 御装置では，通常許される最大操作量(オーソリティ) が決められている。したがって，この場合は評洒㓋準 として, $\int_{0}^{\infty} \theta^{2} d \tau$ と $\left|\delta_{\varepsilon}\right|_{\max }$ をこるのが妥当であろう. この 2 つ曲線加ら，操作量の制御值と渦渡応答との 関係が明瞭しなり，操作量の制限値が与えられると，そ の制限内で最良の過渡応答特性を持つ系が得られる. 第 3 図から，重み係数 $\gamma_{11}$ を 5 以上によっても，操作 量が増すだけで， $\theta$ の応答はほとんど改善されないこ とが加る（䈱 4 図(a)，(b)参照). そこで $\gamma_{11}$ の適当 な值として， $q_{11}^{\prime}=5$ に選ふととにしよう. このとき最 適制到法則は，前に行なったゲイン定数の計算結果か ら,

$$
\begin{aligned}
\delta_{c} & =-2.236 \theta-1.282 \dot{\theta}+0.7852 \alpha \\
& +0.1623 \delta_{c}
\end{aligned}
$$

で与えられる. 

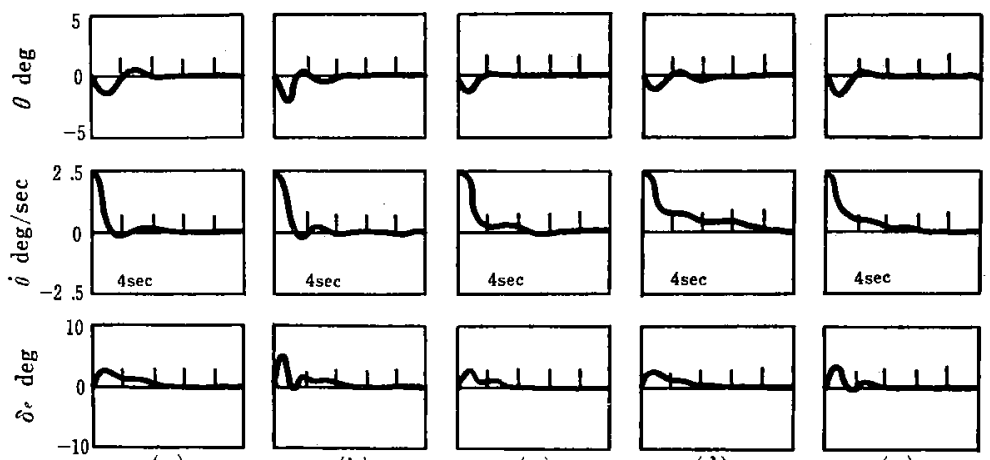

(b)

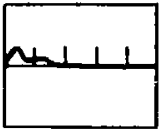

(c)

$\delta \mathrm{c}=2.236 \theta-1.282 \dot{\theta} \quad \delta \mathrm{c}=-5.213 \theta-2.50 \dot{\theta}$ $\begin{array}{ll}+0.785 a+0.1628 \mathrm{e} & +0.99 a+0.2980 \delta \mathrm{e} \\ \mathrm{q}_{11}=5 & \mathrm{q}_{11}=27\end{array}$

$\delta \mathbf{c}=-2.2368$

$-1.282 \dot{\theta}$

(a)を籍单化した采

最適系

過渡地答

\section{4. 徉来の手法との比較}

前節に述ベたシンセシスによる結果を，従来用いら れてきた根軦跡法，および最適制御理論化基つくが重 る係数の决定に根厸跡を用いて得られた結果之比較, 検討する.

4.1 根軌跡法による結果との比較 先に述べた (3.4)式で与えられるような従来の北式の制御系に対 し, BLAKELOCK は，古典的な根軌跡法を用いてゲイ ン定数の值を決定している ${ }^{3)}$. 彼の手法を簡単に説明 しょう. ゲイン定数は $K \theta, K \dot{\theta}$ の 2 個あるので根轨跡

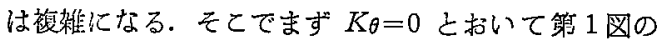
内側ループだけを考えると根轧跡は第 5 図(a)となる. この図から合理的に $K \dot{\theta}$ の值を決めることはできない が，Ki の値を 1.19 と 1.98 の 2 種類とってみる. つ ぎに $K \dot{\theta}$ をこれらの值に固定して全体の系の根軦跡を

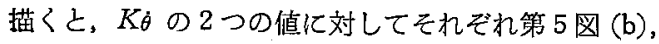
(c)のようになる.ここで振動項のみに着目してその 減衰比が $\zeta=0.6$ 上なるように $K \theta$ を選ぶと, 上に示 した $K \dot{\theta}$ の 2 つ值に対してそれぞれ $K \theta=1.41,3.30$ を得る. 以上の結果に基づいて, 適当な制御法則とし て，彼はつぎの 2 通りのあのを与えている.

$$
\begin{aligned}
& \delta_{c}=-1.41 \theta-1.19 \dot{\theta} \\
& \delta_{c}=-3.30 \theta-1.98 \dot{\theta}
\end{aligned}
$$

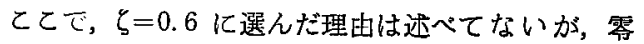
点を含まない 2 次系の振動的な応答については，一般 に $\zeta=0.4 \sim 0.8$ が適当亡さ礼ているので，乙れを拡 張解疎して，同様な值を選んだのであろう．また，は じめに $K \theta=0$ とおいた理由や，つぎに $K \dot{\theta}$ の值を 2 棰類とった理由については根拠がない上うである.

さて彼の与えた制御法則が過当であるかどうかを検 討するために，制御法則(4・1)式に対する過渡応答を，

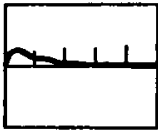

(d)

$\begin{array}{rr}\delta \mathrm{c}=-1.41 \theta & \delta \mathrm{c}=-3.30 \theta \\ -1.19 \dot{\theta} & -1.98 \dot{\theta}\end{array}$

(e)

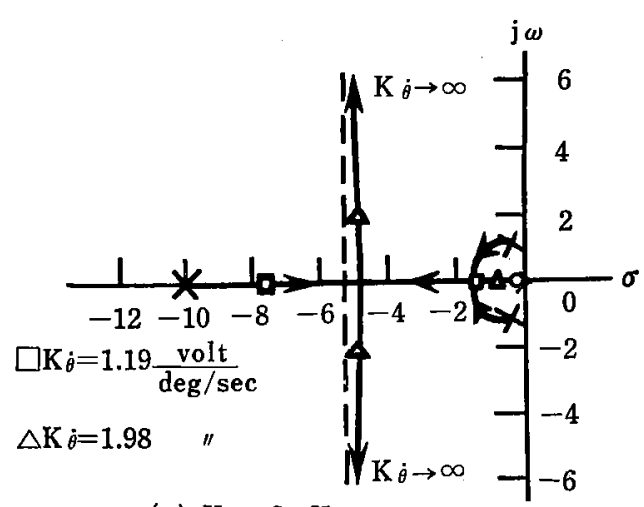

(a) $\mathrm{K}_{\theta}=\mathrm{O}, \mathrm{K} \dot{\theta}$ :variable

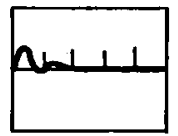

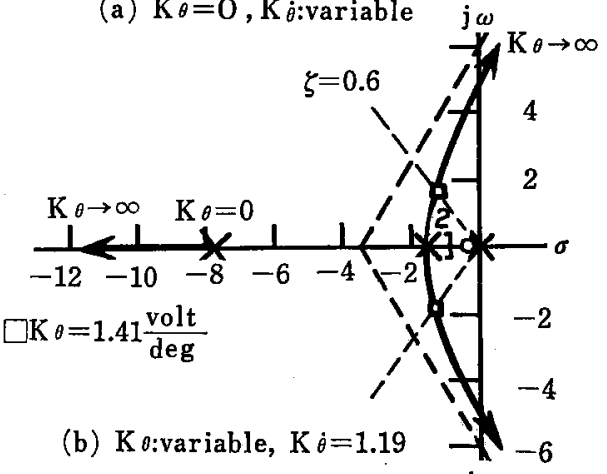

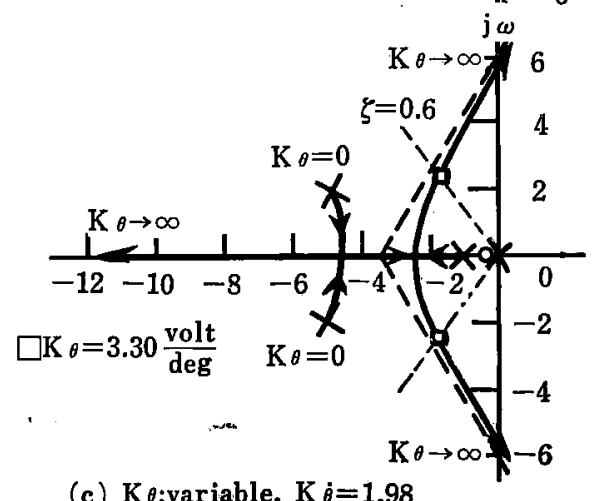

(c) $\mathrm{K} \theta$ :variable, $\mathrm{K} \dot{\theta}=1.98$

第 5 図 従来の制御系の根軋跡 (BLAKELOCK) 
著者の得た最通系 (3.9) 式に対する過渡応答と比較し よう.アナログ計算機で求めたてれらの応答をそれぞ れ，第 4 図 (d)，(e) およで (a) 亿示す。応答 (d), (e) は，従来の根軌跡を用いて， $\zeta=0.6$ となるように設 計された制御系の応答である。しかし，予想したよう な $\zeta=0.6$ 亿対する応答とはかなり異なっているとよ がわかる．乙の理由を調べるために，(d)の $K \dot{\theta}=1.19 ，$ $K_{\theta}=1.41$ の場合のステップ入力に対する過渡応答を 計算すると，第 6 図任すような 4 つのモードの重ね 合わせとなっているととがわかる，乙とで支配的な項 は $\theta_{2}$ であって，予想したような 2 次の振動モード $\theta_{4}$ でない，このことは，振動モードだけの根轨跡に注目 して $\zeta=0.6$ と定めても烸意味であるととを示してい る.

一般に根軌跡による設計法は，過渡応答を支配する 振動項の $\zeta や \omega_{n}$ 亿着目して所望の過渡特性を得よう とするあのであるが，乙の考えは妥当でない場合が多 い.というのは，応答が多くのモードの重稀わさっ たあのであるときは，単純に 1 つの振動モードのらや $\omega_{n}$ だけでは，系の過渡特性を判定できないからであ る. このように，根軌跡だけに頼る手法は，(1) 多く のフィドバックを持つ系や多変数制御系では根軌跡が 非常に複雑になるばかりでなく，(2) 根恍跡が求まっ ても，そ扎から適当なゲイン定数の值を選択するが困 難であることが加る.

\section{2 重み係数の決定に根軌跡を利用した方法と比} 较 2 で提案したような，過渡応答特性の数值評価に 上って重み係数を決定する方法のほかに，さきに著 者 ${ }^{11}$ および RYNASKI ら ${ }^{4), 5)}$ は，重み係数と最適系の特 性根とのような関保を求め, 望ましい特性根の值か ら，逆汇重み保数を決めるこ之を試みた．重み保数と 最適系の特性根との関係はつぎの特性方程式で与えら れる4.

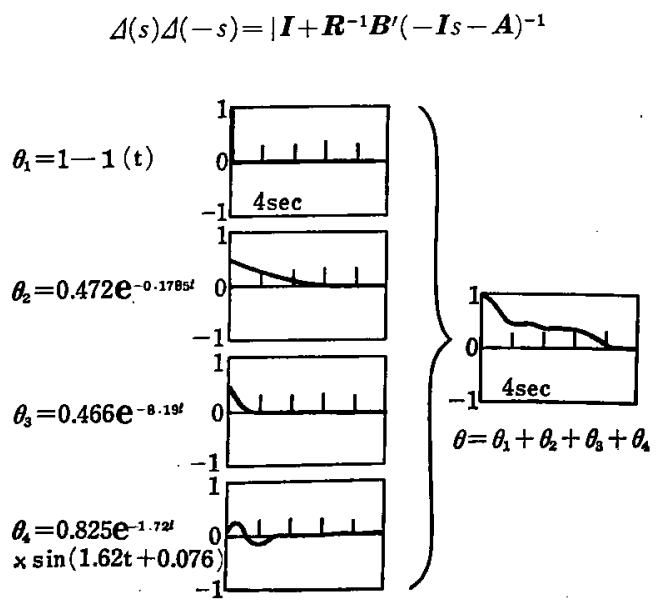

第 6 図 從来の系の過效応答の解析

$$
\times \boldsymbol{Q}(\boldsymbol{I} s-\boldsymbol{A})^{-1} \boldsymbol{B} \mid=0
$$

さきに述べた（3.5）式の系に対して，(3.6) 式の評 価関数を選んだ場合は，

$$
\begin{aligned}
& 1+1.876 \times 10^{2} \gamma_{11} \frac{(s+0.306)}{-s^{2}(s+10)(-s+10)} \\
& \times \frac{(-s+0.306)}{\left(s^{2}+0.805 s+1.325\right)\left(s^{2}-0.805 s+1.325\right)}=0
\end{aligned}
$$

となる.この式から，重み係数 $\gamma_{11}$ をパラメータにし て根䊑跡を描くと，虚軸に関して対称で原点に対して 放射状の，いわ沙る BUTTERWORTH 型となる. との うち右半平面の軌跡梳随伴系のものであるからてれを 省略して，左半平面だけを描く之第 7 図となる. 第 7 図を見ると，振動根は $\zeta=0.5$ 亿漸近していて， $\gamma_{1}$ の值によってらの值はあまり变わらない.したがて,て の場合はとを設計基準として $\gamma_{11}$ を選定することはで きない，結局この手法も，根軌跡を用いて所望の過渡 応答特性を得ようとするものであるから，本質的に古 典的根軌跡法之同じ久点を持っているといえる。すす

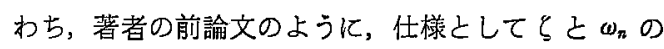
最適值が与えられている場合は別であるが，一般に ? や $\omega_{n}$ だけから過渡応答を推定するてとは因難である このような手法は，最適制御理諭という有力な手法を 用いながら，重要な点であいまいな従来の判定基準代 頼っているわけで，古典理論への逆行であるというこ とができよう.

4.3 最適制御系の構成法に関するノート ここで は，最適制御系の制御法則の構成について付け加えて おこう. 最適制御法則は，すべての状態変数の一次結 合の形で与えられる.したがって，従来のように制御

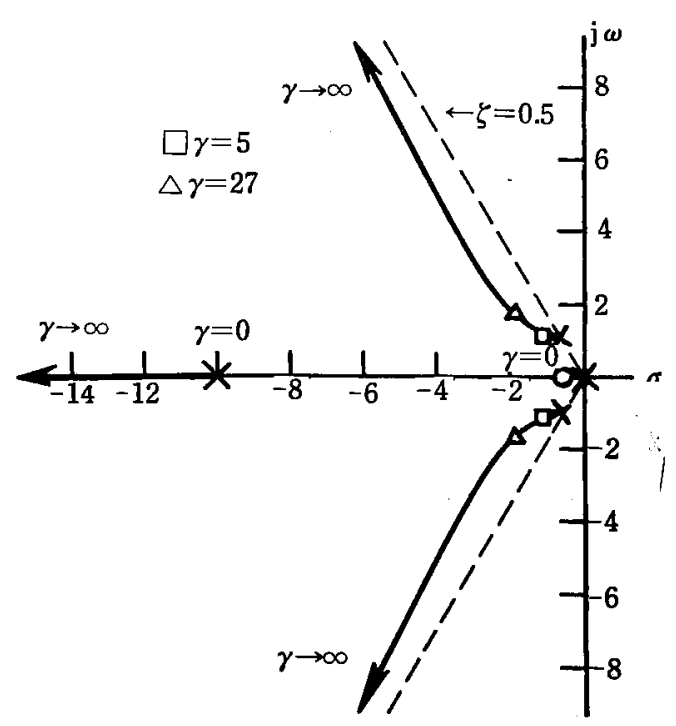

第 7 図 重み保数をパラメータにした最適采の根蝶跡 
法則を与えた場合に比べて一般に複雑になる。しかし 実際には，てれらすへての変数を検出するセンサがな かったり，丞をもっと簡単にしたいととが多い．との 点加ら，最適制御系は現実的ではないという意見もあ

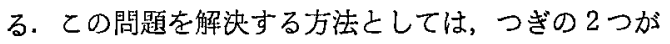
考えられる.すなわち，

(1) 柔が線形であるときは，各変数は伝些関数で 関係つりりれている.したがって，検出しにくい翌数 や検出不可能な変数は, すでに検出されている変数か ら，伝達関数を挿入することによって知ることができ る. すなわち、すべての変数を検出する必要はない.

(2) 最適系のフィードバック量のうち, ゲインが 小さく，応答に影響の少ないものがあれば，これを省 略して制御系を簡単化するとともできる.

以下において，同じ計算例についててのような棈成 法を考えてみよう. 最適制御系のブロック線図第 2 図 よりわかるように，との系の構成には，迎え解 $\alpha$ を検 讪する必要がある。しかし現在では，精度の良い迎え 角センサを得るととはかなり困難である、そこで，上 に述べた（1）の方法を考える。（2.5）式をラプラス変 換して， $\bar{\delta}_{\epsilon}$ を消去してて $\bar{\alpha}$ と市の関係を求めると，

$$
\frac{\bar{\alpha}}{\overline{\dot{\theta}}}=0.0129 \frac{s+77.75}{s+0.306}
$$

となる.すなわち、レート・ジャイロで主を検出する 之， $\alpha$ は (4-4) 式の伝達関数の回路を挿入するととに よって得るととができる、とのようにすれば迎え角の センサを使わなくて最適制御系を構成することができ る.

つぎに，(2)の方法を考える、(3.9)式なる最適制御 法則のうち， $\alpha$ と $\delta_{e}$ のフィードバックを省略すると， 制衙法則は，

$$
\delta_{c}=-2.236 \theta-1.282 \dot{\theta}
$$

となる，乙のときの応答は，第 4 図(c)のようになる.

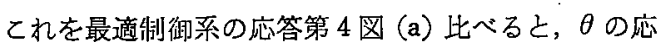
答特性が劣っているので，ての簡単化は適当であると はいえない，しかし，根轨跡法によって得られた系の 第 4 図 (d)，(e)に此べるとすぐれている.

なお， $\delta_{e}$ のフィードバックの代わりに，サーボの 時定数を変更することによって, 同じ效果を得ること ができる。

\section{VTOL 機の自動安定装置のシンセシス}

VTOL の槛運動に対する自動安定装置のシンセシ スを考える. 一般に，横方向の運動については，横摇 れ電動の御御と片摇れ運動の制御が考えられる．この ような，2つの入力をむつ多変数制御系を，古典的根 軌跡法のような従来の線形制御理論によって扱うと，

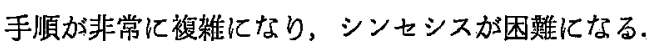
2で与えた著者らの手法を適用すると，このような制 御系に対しても，1入力の場合を同様の手順によっ て，系統的なシンセンシスが可能である.

5.1 VTOL 機の運動方程式 ホバリングおよび低 速飛行中の VTOL 機の横の運動方程式は, 微少運動 の筋囲では，つぎのような線形微分方程式で表わされ る.

$$
\left.\begin{array}{l}
L_{v} v+L_{p} \dot{\phi}-I_{X} \ddot{\phi}=-L_{\delta_{R}} \delta_{R} \\
Y_{u} v-m \dot{v}+m g \phi=0 \\
N_{u} v+N_{r} \dot{\phi}-I_{Z} \ddot{\phi}=-N_{\delta} \delta_{Y}
\end{array}\right\}
$$

ここに, v: 横すべり速度, $\phi$ : 横摇れ角, $\phi$ : 偏摇れ 角, $I_{X}$ : 重心まわりの機体の横摇れ慣性モ一 メント， $I_{Z}$ : 重心まわりの機体の偏摇れ慣性 モーメント, $m$ : 機体の質量, $L \delta_{R}, N \delta \mathrm{Y}$ : 横 摇れおよび偏摇れモーメントに対する操維感 度, $L_{v}, L_{p}, Y_{v}, N_{v}, N_{\tau}$ : 空力微係数, $g$ : 重 力加速度, $\delta_{R}$ : 横摇れ制御の操縦桿変位, $\delta_{Y}$ : 偏採れ制御のペダル変位, ・: 時間に関 する微分

である.

状態変数として, $x_{1}=\phi, x_{2}=\dot{\phi}, x_{3}=v, x_{4}=\dot{\phi}$ をと れば，(5・1)式はつぎの状態方程式で書きかえられる.

$$
\begin{aligned}
& {\left[\begin{array}{c}
\dot{x}_{1} \\
\dot{x}_{2} \\
\dot{x}_{3} \\
\dot{x}_{4}
\end{array}\right]=\left[\begin{array}{cccc}
0 & a_{12} & 0 & 0 \\
0 & a_{22} & a_{23} & 0 \\
a_{31} & 0 & a_{33} & 0 \\
0 & 0 & a_{43} & a_{44}
\end{array}\right]\left[\begin{array}{c}
x_{1} \\
x_{2} \\
x_{3} \\
x_{4}
\end{array}\right]} \\
& + \\
& +\left[\begin{array}{cc}
0 & 0 \\
b_{21} & 0 \\
0 & 0 \\
0 & b_{42}
\end{array}\right]\left[\begin{array}{l}
\delta_{R} \\
\delta_{Y}
\end{array}\right]
\end{aligned}
$$

ことに, $a_{12} 1, \quad a_{22}=L_{p} / I_{X}, a_{23}=L_{v} / I_{X}, \quad \dot{a}_{31}=g$, $a_{34}=Y_{v} / m, \quad a_{43}=N_{u} / I_{Z}, a_{44}=N_{\tau} / I_{Z}$, $b_{21}=L_{\delta_{R}} / I_{X}, \quad b_{42}=N_{\partial Y} / I_{Z}$

である。

5.2 自動安定装置のシンセシス 横摇れおよび偏 摇れ制御のための操作量のオーソリティを考慮して, 出力の偏差の 2 乘樍分值を最小にする制御法則を得る ために，評価関数をつぎのように選ぶ.

$$
\begin{aligned}
I= & \int_{t}^{\infty}\left(\alpha_{1} x_{1}^{2}+\alpha_{2} x_{2}^{2}+\alpha_{3} x_{3}{ }^{2}+\alpha_{4} x_{4}{ }^{2}\right. \\
& \left.+\beta \delta_{Y}{ }^{2}+\delta_{R}^{2}\right) d \tau
\end{aligned}
$$

この評価関数の中に，少位保持のための中を含めなか ったのは，てれを加えるとかえって運航上不都合を生 じると考えられる办らである6

(5・2) 式で記速される例微系において, 評㑊関数 (5.3) 式を最小にするような最適制御法則は, 次式で 与えられる。 


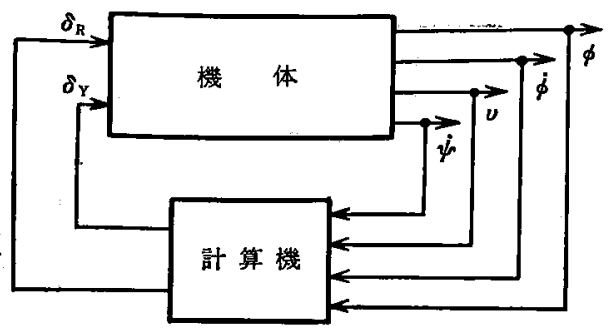

第 8 図 VTOL の横の自動安定装置

$$
\left.\begin{array}{l}
\delta_{R}=-b_{21}\left(K_{21} x_{1}+K_{22} x_{2}+K_{23} x_{3}+K_{24} x_{4}\right. \\
\delta_{Y}=-\frac{b_{42}}{\beta}\left(K_{41} x_{1}+K_{42} x_{2}+K_{43} x_{3}+K_{44} x_{4}\right)
\end{array}\right\}
$$

この系のブロック線図は第 8 図となる.ここで， $K_{21} \sim K_{24}, K_{41} \sim K_{44}$ は，それぞれ，つぎのリッカチ方 程式の $P_{12} \sim P_{24}, P_{14} \sim P_{44}$ の定常解で与えられる.

$$
\begin{aligned}
& \dot{P}_{11}=2 a_{31} P_{13}-b_{21}^{2} P_{12}{ }^{2}-\frac{b_{42}{ }^{2}}{\beta} P_{14}{ }^{2}+\alpha_{1} \\
& \dot{P}_{12}=a_{12} P_{11}+a_{22} P_{12}+a_{31} P_{23}-b_{21}^{2} P_{12} P_{22} \\
& -\frac{b_{42}{ }^{2}}{\beta} P_{14} P_{24} \\
& \dot{P}_{13}=a_{23} P_{12}+a_{33} P_{13}+a_{43} P_{14}+a_{31} P_{33} \\
& -b_{21}^{2} P_{12} P_{23}-\frac{b_{12}{ }^{2}}{\beta} P_{14} P_{34} \\
& \dot{P}_{14}=a_{44} P_{14}+a_{31} P_{34}-b_{21}^{2} P_{12} P_{24} \\
& -\frac{b_{42}^{2}}{\beta} P_{14} P_{44} \\
& \dot{P}_{22}=2 a_{12} P_{12}+2 a_{22} P_{22}-b_{21}^{2} P_{22}^{2} \\
& -\frac{b^{2}{ }_{42}}{\beta} P_{24}{ }^{2}+\alpha_{2} \\
& \dot{P}_{23}=a_{23} P_{22}+\left(a_{22}+a_{33}\right) P_{23}+a_{43} P_{24} \\
& +a_{12} P_{13}-b_{21}{ }^{2} P_{22} P_{23}-\frac{b_{42}{ }^{2}}{\beta} P_{24} P_{34} \\
& \dot{P}_{24}=\left(a_{22}+a_{44}\right) P_{24}+a_{12} P_{14}-b_{21}^{2} P_{22} P_{24} \\
& -\frac{b_{42}{ }^{2}}{\beta} P_{24} P_{44} \\
& \dot{P}_{33}=2 a_{23} P_{23}+2 a_{33} P_{33}+2 a_{43} P_{34} \\
& -b_{21}^{2} P_{23^{2}}-\frac{b_{42}{ }^{2}}{\beta} P_{34^{2}}+\alpha_{3} \\
& \dot{P}_{34}=\left(a_{33}+a_{44}\right) P_{34}+a_{23} P_{24}+a_{43} P_{44} \\
& -b_{21}^{2} P_{23} P_{24}-\frac{b_{42}{ }^{2}}{\beta} P_{34} P_{44} \\
& \dot{P}_{44}=2 a_{44} P_{44}-b_{21}^{2} P_{24}{ }^{2}-\frac{b_{42}{ }^{2}}{\beta} P_{44}{ }^{2}+\alpha_{4}
\end{aligned}
$$

評価関数 (5.3) 式の重み係数の值が与えられると, 上式を解いて，(5.4) 式の最過制御法則のゲイン定数 が求まる. 重み係数の值は， 2 に述べた手順に従って 決定する.

5.3 数值例 計算に使用する機体の要目はつぎの
とおりである゙.

機体: Tilt Duct 型 Doak VZ-4,

$m=143.5 \mathrm{~kg} \cdot \mathrm{sec}^{2} / \mathrm{m}, I_{X}=262 \mathrm{~kg} \cdot \mathrm{m} \cdot \mathrm{sec}^{2}$

$I_{z}=476 \mathrm{~kg} \cdot \mathrm{m} \cdot \mathrm{sec}^{2}, L_{P} / I_{X} \triangleq a_{22}=-0.4551 / \mathrm{sec}$

$L_{0} / I_{X} \triangleq a_{23}=-0.073491 / \mathrm{sec}, g \triangleq a_{31}=9.8 \mathrm{~m} / \mathrm{sec}^{2}$

$Y_{v} / \mathrm{m} \triangleq a_{33}=-0.28951 / \mathrm{sec}$

$N_{v} / I_{Z} \triangleq a_{43}=0.026571 / \mathrm{m} \cdot \mathrm{sec}$

$N_{Y} / I_{Z} \triangleq a_{44}=-0.6551 / \mathrm{sec}$

$L_{\delta} / I_{X} \triangleq b_{21}=-10.01 / \mathrm{m} \cdot \mathrm{sec}^{2}$

$N_{\delta \mathrm{Y}} / I_{Z} \triangleq b_{42}=-10.01 / \mathrm{m} \cdot \mathrm{sec}^{2}$

以上の数值を $(5 \cdot 2)$ 式に代入すると，状態方程式は つぎのようになる.

$$
\begin{aligned}
{\left[\begin{array}{l}
\dot{x}_{1} \\
\dot{x}_{2} \\
\dot{x}_{3} \\
\dot{x}_{4}
\end{array}\right] } & {\left[\begin{array}{cccc}
0 & 1 & 1 & 0 \\
0 & -0.455 & -0.07349 & 0 \\
9.8 & 0 & -0.2895 & 0 \\
0 & 0 & 0.02657 & -0.655
\end{array}\right] } \\
& \times\left[\begin{array}{c}
x_{1} \\
x_{2} \\
x_{3} \\
x_{4}
\end{array}\right]+\left[\begin{array}{cc}
0 & 0 \\
-10 & 0 \\
0 & 0 \\
0 & -10
\end{array}\right]\left[\begin{array}{l}
\delta_{R} \\
\delta_{Y}
\end{array}\right]
\end{aligned}
$$

この制御系に対して，最適制御法則を求めるために 評価関数を式で (5.3) 与える. しかし，との諭文の手 法では，重み係数をパラメータと考えているので，な るべく簡単な評価関数を選んだオが計算量が少なくて すむ. したがって，(5.3）式のうち，さらに真に評価 すべき状態変数のみを残し，評俌関数を簡単にするの が得策である.との例では，横摇れおよび偏摇れ運動

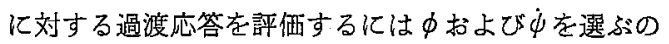
が適当であろうと考えられる. そとで， $\alpha_{2}=\alpha_{3}=0$ とおいて，つぎのような評価関数を用いるととにす ๖.

$$
I=\int_{t}^{\infty}\left(\alpha_{1} x_{1}^{2}+\alpha_{4} x_{4}^{2}+\beta \delta_{Y}^{2}+\delta_{R}^{2}\right) d \tau
$$

そこで, 重み係教 $\alpha_{1}, \alpha_{4}, \beta$ の值を系統的に変化 させて, リッカ千方程式 (5.5) 式を解けば，各場合に ついてゲイン定数 $K_{21} \sim K_{24}, K_{41} \sim K_{44}$ が求められる. つぎに，てのようにして求まったゲイン定数の值に対 する過渡応答と，過渡応答を評価するための特性值を アナログ計算機によって求める.VTOL 機の横の自動 安定装置の設計では，横摇れ角に掜乱をうけたときの 過渡応答特性と，横風の影響によって横すべり速度を 持ったときの過渡応答特性が重要な意味を持つので8) これらの過渡応答を求める. 横摇れ運動の過渡特性を 判定する特性值として $\int_{0}^{\infty} \phi^{2} d \tau$ と $\left|\delta_{R}\right|_{\max }$ を計算し, 偏 摇れ運動の過渡特性を判定する特性值として $\int_{0}^{\infty} \dot{\psi}^{2} d \tau$ と $\left|\delta_{x}\right|_{\max }$ を計算する. との上き横摇れ運微と偏摇れ 運動の速成が小さい場《には，これらの2つの過渡応 
答特性を別々に評価することができる．いま(5.7) 式 の評埏関数を畫きかえるとつぎのようになる。

$$
\begin{aligned}
I= & \int_{t}^{\infty}\left(\alpha_{1} x_{1}{ }^{2}+\delta_{R}{ }^{2}\right) d \tau \\
& +\beta \int_{t}^{\infty}\left(\frac{\alpha_{4}}{\beta} x_{4}^{2}+\delta_{Y}{ }^{2}\right) d \tau
\end{aligned}
$$

上式第 1 項は横摇れ角制御のための萼価関数，第 2

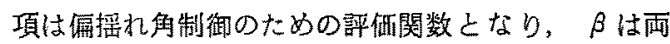
者の関の連成に関係する重み係数とみなすことができ る. したがって，連成が小さいときは，第 1 項と第 2 項を分離して考えることができ， $\beta$ の値には依存し ない，すなわち，系の特性は，横摇れ運動に対しては $\alpha_{1}$, 篇摇れ運证化対しては $\alpha_{4} / \beta$ の值によってきま る.

実際，この例で横摇れ角に娘乱をうけた上きの過渡 応答に対する特性值をアナログ計算譏で求める上，偏 摇れ運動の特性を表わす $\int_{0}^{\infty} \phi^{2} d \tau$ および $\left|\delta_{Y}\right|_{\max }$ はき わめて小さく，偏摇れ運動にはほとんど影響しないこ とがわかった，したがって，とのときは横摇和運動の 過渡特性のみに注目することができる。そこで， $\int_{0}^{\infty} \phi^{2}$ $\times d \tau\left\llcorner\left|\delta_{R}\right|_{\max }\right.$ の值を重み係数 $\alpha_{1}$ に対してプロッ トすると第 9 図のようになる.ここで，先に述べたよ うに, $\int_{0}^{\infty} \phi^{2} d \tau$ およじ $\left|\delta_{R}\right|_{\max }$ に対する $\alpha_{4}, \beta$ の影 響は小さいので，てれを無視している，つぎに，棤す べり速度を持ったときの過渡応答に対する特性值を求 める.このときは，横摇れ運铺に対する連成が小さい ので扎を省略し，编摇㣗運邪の過渡特性のみ注目 する. $\int_{0}^{\infty} \dot{\phi}^{2} d \tau$ および $\left|\delta_{Y}\right|_{\mathrm{mx}}$ の值を $\alpha_{4} / \beta$ に対してブ ロットすると，第 10 図のようになる，第 9 図および

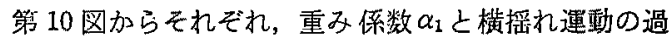
渡応答特性， $\alpha_{4} / \beta$ と偏摇れ運勤の過渡応答特性との関 係が明瞭となり，操作量のオーソリティを考慮して望 ましい過渡応答特性をすつように重み係数を決定する

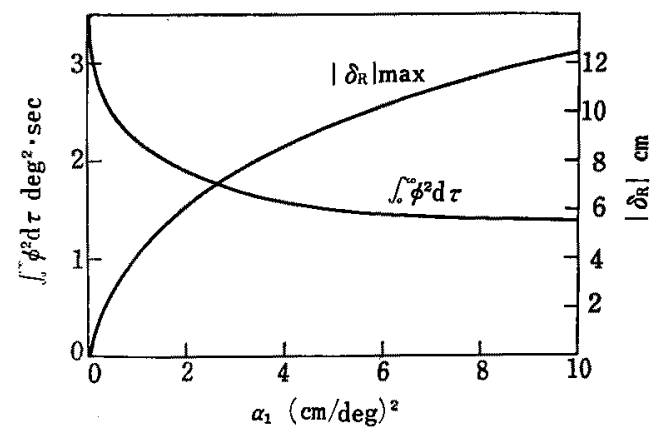

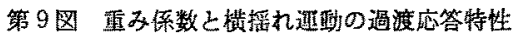
$\left(\phi_{0}=2.5 \mathrm{deg}\right)$

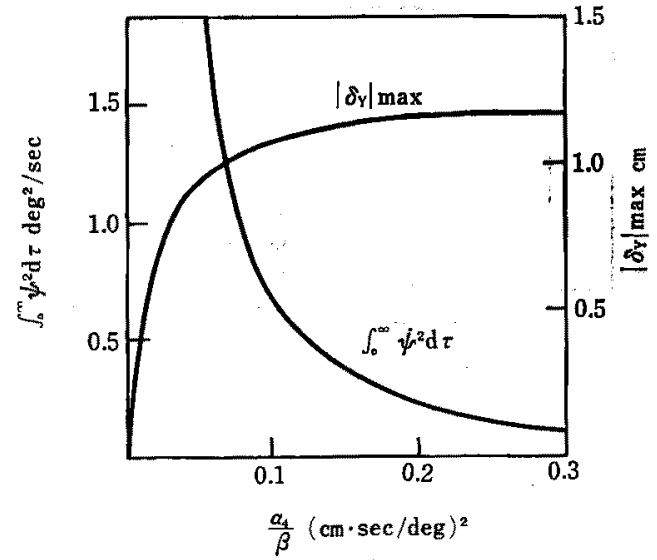

第 10 図 重み你数之偏播れ運動の過渡特性 $\left(v_{0}=5 \mathrm{~m} / \mathrm{sec}\right)$

こをができる．とてで $\beta$ は，さきに述べたように，

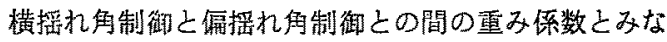
すことができるので，との例のように両者の連成が小 さいときには問題にならない，連成が出いときは， $\beta$ をパラメータとして第 9 図し同㥞の図を描けばよい，

第9図および第 10 図から需み係数の適当な値とし $\tau \alpha_{1}=1, \alpha_{4} / \beta=0.125\left(\alpha_{4}=0.5, \beta=4\right)$ 之選ふと, 最適制御法則は，

$$
\left.\begin{array}{rl}
\delta_{R} & =1.001 \phi+4.042 \cdot 10^{-1} \dot{\phi} \\
& -6.004 \cdot 10^{-3} v+2.016 \cdot 10^{-3} \dot{\phi} \\
\delta_{Y} & =4.078 \cdot 10^{-3} \phi+5.040 \cdot 10^{-4} \dot{\phi} \\
& +2.011 \cdot 10^{-3} v+2.940 \cdot 10^{-1} \dot{\phi}
\end{array}\right\}
$$

となる.ここに, 各変数の単位は, $\phi[\mathrm{rad}], \phi, \phi[\mathrm{rad}$ /sec $], v[\mathrm{~m} / \mathrm{sec}), \delta_{R}, \delta_{Y}(\mathrm{~m}]$ である. $\phi[\mathrm{deg}), \dot{\phi}, \dot{\phi}$ $[\mathrm{deg} / \mathrm{sec}], v[\mathrm{~m} / \mathrm{sec}], \delta_{R}, \delta_{Y}[\mathrm{~cm}]$ に単位を变換すれ II,

$$
\left.\begin{array}{rl}
\delta_{R} & =1.747 \phi+0.7054 \dot{\phi} \\
& -0.6004 v+0.003518 \dot{\phi} \\
\delta_{Y} & =\dot{\psi} 0.007116 \phi+0.0008796 \dot{\phi} \\
& +0.2011 v+0.5131 \dot{\phi}
\end{array}\right\}
$$

となる。

このときの過渡応答を第 11 図，第 12 図に示す. 第 11 区心横摇れ角 $\phi$ 亿摖舌をうけたときの過渡応答を 示し，第 12 図は横すべり速度を持ったよきの過渡応 答を示す，耐図において，(a) は自動安定装膘を持た ない元の VTOL 機の応答を示す. (b) は今求めた最 適删御系の応答である: (c) は最適制御法則のうち, フィードバック・ゲインの小さい項を畄略して，

$$
\begin{aligned}
& \delta_{s}=1.747 \phi+0.7054 \dot{\phi}-0.6004 v \\
& \delta_{y}=0.2011 v+0.5131 \dot{\phi}
\end{aligned}
$$

の形に簢篻化した制御法則をすつ近似最適系の応答て ある.（d)は偏摇れ制微 $\delta_{Y}$ を省略したときの店答てあ る.図をみると，との近似最適系の忙答 (c) は最適系 


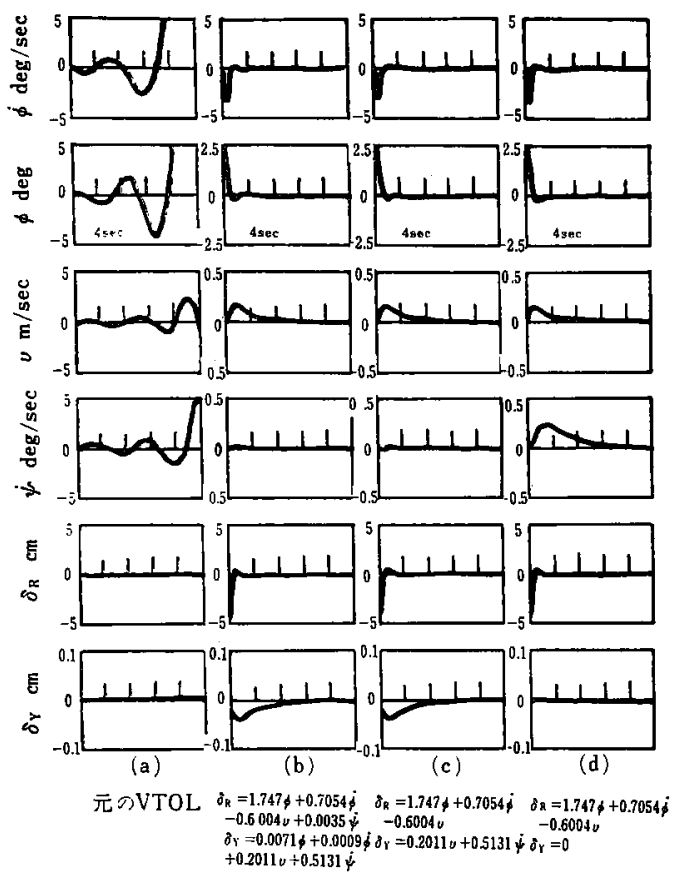

第 11 図VTOLの横准動の過洨応答 $\left(\phi_{0}=2.5 \mathrm{deg}\right)$

の応答 (b) とほとんど变わらず，このような簡単化は 適当であるととがわかる，偏摇㣗制御 $\delta_{Y}$ を行なわな い上きは，横摇れ運動の過渡応答特性にはあまり影響 しない(第 11 図(d)) が，樸風をうけたときの偏摇れ 角の応答が非常に劣る（第 12 図 (d)). したがって, このような系では $\delta_{Y}$ を省略して 1 変数制御系として 考えるととはできない.

\section{6. 結 論}

この論文では，従来の根杣跡による手法や，根軌跡 を利用した最適制御理諭による手法に代わるすのよし て, 過渡特性の数值評佂に基づく最適制御理論による 楾形フィードバック制衔系のシンセシスの方法を提案 した.この手法の適用例として, 普通の航空機の姿蓺 制御装置と，VTOL 機の自動安定装置シンセシスを 示した．との手法を彷来のむのと比校するとつぎのよ うになる。

（1）従来の根軦跡法では，制御采の粠成を仮定し て試行鍇言的に最適構成を模索したが，最適制御理論 を用いた手法では，評価関数から解析的に最適制御法 則が誘導される.

（2）徉来の根軦跡法では，多重ループを含む 1 変 数制御系や多变数制御系をシンセシスするさい，多数 個のフィードバック・ゲイン值を決定することは非常 に困難である. これに対して，最適制御理論による方 法では，これらの值は重み係数の值から一度に決定さ

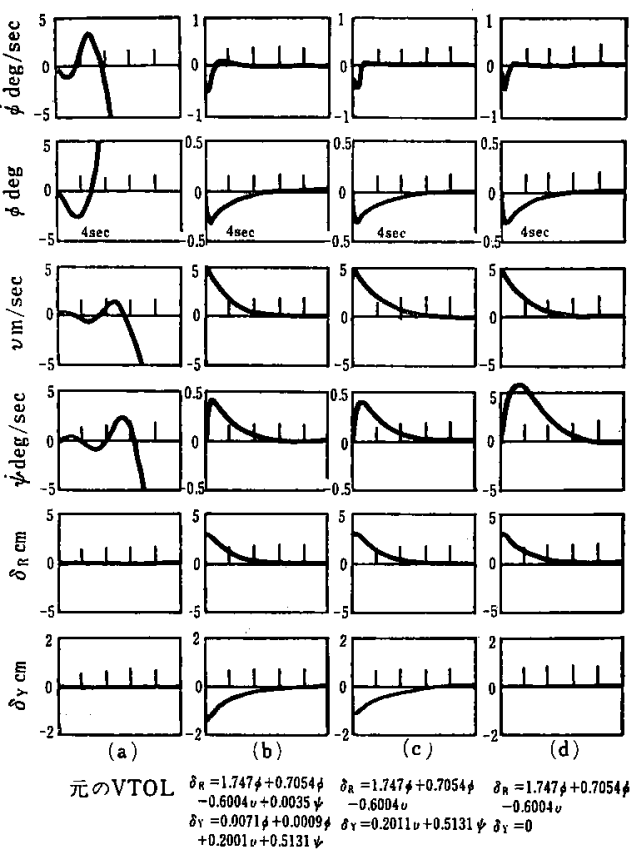

第 12 図 VTOLの枮荤動の過渡応答 $\left(v_{0}=5 \mathrm{~m} / \mathrm{sec}\right)$

れる.したがって，多重ループを含む 1 変数制御系の シンセシスが容易に行なえるばかりでなく，多変数制 御系の場合む，同一の手法を適用して系統的なシスセ シスが可能である.

（3）最適制御理論を用いてす，根軦跡を併用する 方法では，重み係数が 2 つ上ある場合のシンセシス がきわめて困難となる，過渡応答特性の数値評価に基 づく方法では，計算量が増すだけであって，本質的な 困難は生じない。

（4）従来の根轨跡による手法や，根軌跡を用いた

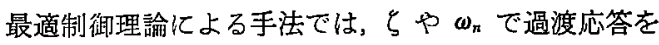
正確に評価するととができないので設計の根拠があい まいである.これに対して，過渡特性の数值評佂に基 つく方法では，過渡応答を定量的に評洒することがで きる.すなわち，制御量の大きさと過液特性の関係が 明らかになり，制御のオーソリティが与えられると， そのオーソリティ内で最良の過渡特性を持つ系を構成 することができる。したがって，機械的な計算とよる 系統的なシンセシスが可能となる.

(5) 最適系では, フィードバックする変数の数が 多くて，系の構成が複雑になるが，乙机を簡単化する 方法も考えられる. 古典理論では経験に基づいて簡単 な系を仅定してきたが，最適制御理諭では，合理的に 系を簡笚化できる.

とこに提案した方法は，最適制御理論を設計訃算の 手順を与える数学的手段として利用し, 最適解の計算 
および過渡応答の判定篮準となる特性値の計算をすべ て電子計算機で処理しようとするもので，一種の computer-aided design であるということができる. とと では，ディジタル部算機とアナログ計算機を併用した が，すべてディジタル計算機のみによって処理するこ 上すできる，また，将来ハイブリッド計算機が普及す れば，てのような手法は一層有力なるのとなるであろ 5 .

計算の一部は東宗大学大型計算機センターに依頼し た。 記して謝意を表する。

\section{参考文献}

1）中川，室津，金定：重直離着陸航空機の最適姿勢制御 における評価関数の重み係数選択関する一考察; 制 御工学, Vol. 10 No. 12, pp. 518-525 (1966).

2) R.E. Kalman: Contributions to the Theory of
Optimal Control; Bol. Soc. Mat. Mex., Vol. 5, pp. 102-119 (1960).

3) J.H. Blakelock : Automatic Control of Aircraft and Missiles (Book); John Wiley \& Sons, Inc. (1965).

4) E. G. RynaskI : Optimal Helicopter Station Keeping: IEEE Trans. on Automatic Control, Vol. AC-11, No. 3, pp. 346-355 July (1966).

5) J.S. TYler \& F.B. Tuteur: The Use of a Quadratic Performance Index to Design Multivariable Control Systems; IEEE Trans., Vol. AC-9, No. 3, pp. 84-92 Jan. (1966).

6）武田，垒川，小川，森：航技研フライング・テスト・ ベッドの资勢制御方式の㭘討；航技研報告 TR-120 (1966)

7) R. H.Sмiтн: VTOL Control Power Requirement Reappraised; J. Aircraft, Vol. 3. No. 1, Jan. -Feb. (1966).

8）武田, 滰沢：VISTOL 機の飛行性基準; 日本航空学 会誌, Vol. 15, No. 157, pp. 58-64 (1967)

\section{表紙写真説明}

京都大学工学部航空工学教室では昭和 42 年 3 月末 超空気力学実験室加閒設され, 実在気体勃果を伴う極 超音速空気力学の研究を目的として極超音速ガン・タ ンネル (大型)，ピストン駆動型衝撃波管およで，プ ラズマ・ジェット風胴（航空学会誌に既に報告ずみ）

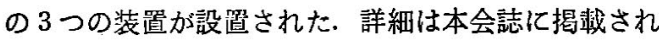
ているので省略するが，写真左侧は䟲尾部より除身部 を経て測定室の方を示しているガン・タンネルであ り，てれに平行して右側には銃尾部，低圧室，測定部 およびダンプ・タンクと連結した上記の衝撃波管であ る. 前者では測定室マッ八数 $10,12,14,16$ の極超音速 流，後者では衝撃マッ八数 26 までの強い衝撃波を得
ることができる，この㿤験室は宇治市五ケ庄京大宇治 構内にある.

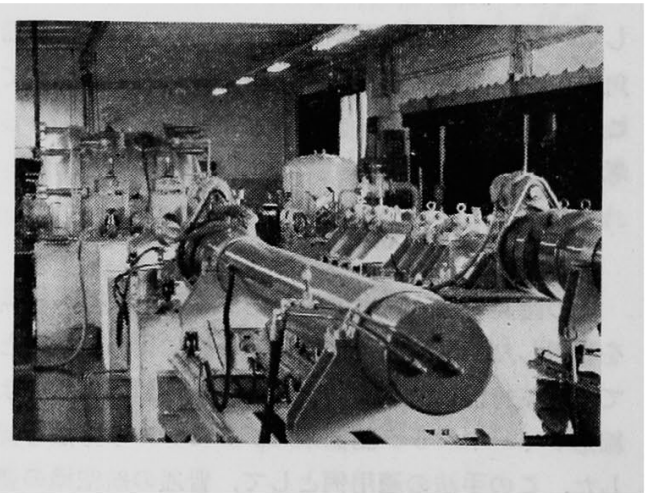

